\title{
$\mathrm{Ku}$ 대역 모노펄스 위성추적을 위한 동축구조 도파관 고차모드 커플러 설계
}

\author{
가 득 현*, 박 도 현", 송 충 호", 안 성 준**, 전 찬 원*, 이 재 문
}

\section{Design of a Higher-Order Mode Coupler Using Coaxial-Structure Waveguide for Ku-Band Monopulse Satellite Tracking}

\author{
Deuk-hyeon $\mathrm{Ga}^{*}$, Do-hyun Park ${ }^{*}$, Choong-ho Song ${ }^{*}$, Sung-joon Ahn ${ }^{* *}$, \\ Chan-won Jun ${ }^{* *}$, Jae-moon Lee
}

요 약

본 논문은 $\mathrm{Ku}$ 대역 모노펄스 위성추적을 위한 동축구조 도파관 고차모드 커플러를 제안하였다. 제안된 고차모드 커플러는 이동체 탑재용 위성추적시스템에 적용 가능하도록 소형/경량화를 위하여 동축구조의 도파관을 이용하였 다. 기본모드 신호 추출을 위해 내측 원형도파관을 이용하였고, 고차모드 신호 추출을 위해 외측 원형도파관에 내 어진 4개의 슬롯과 스텝 구조의 직사각형 도파관을 이용하였다. 제안된 고차모드 커플러의 모의실험 결과는 반사 손실 및 삽입손실이 약 $250 \mathrm{MHz}$ 의 대역폭(12.75 13.00 GHz)을 만족하며, 모노펄스 추적에 적용 가능한 기본모 드 패턴 및 고차모드 패턴이 만족스럽게 생성된 결과를 확인하였다. 제안된 $\mathrm{Ku}$ 대역 동축구조 도파관 고차모드 커 플러는 고속 정밀추적이 요구되는 모노펄스 위성추적시스템에 이용될 것으로 기대된다.

Key Words : monopulse tracking, satellite, radar, mode coupler, coaxial-structure WG

\section{ABSTRACT}

In this paper, a higher-order mode coupler using coaxial-structure waveguide for $\mathrm{Ku}$-band monopulse satellite tracking is proposed. The proposed higher-order mode coupler is built in a coaxial structure for compactness and weight reduction, making it suitable for mobile tracking systems. The inner circular waveguide of coaxial-structure is used to extract the fundamental mode signal and the high-order mode signal is extracted from the four slots of the outer circular waveguide and then transmitted via given stepped rectangular waveguide structure. The simulated results show that proposed higher-order mode coupler covers $250 \mathrm{MHz}(12.75 \mathrm{GHz}$ 13.00 GHz) bandwidth with return loss and insertion loss characteristics. The antenna patterns of fundamental mode and higher-order mode applicable to monopulse tracking are generated successfully. Designed higher-order mode coupler using coaxial waveguide structure for Ku-band is expected to be used for high precision monopulse satellite tracking systems.

- First Author and Corresponding Author : LIG Nex1 Co.,Ltd. Communication R\&D Lab, deukhyeon.ga@lignex1.com, 정회원

* LIG넥스원(주) 통신연구센터 1팀, dohyun.park@lignex1.com, choonghosong@lignex1.com

** 국방과학연구소 제2기술연구본부 1부, xhxhfh@add.re.kr, jun6060@add.re.kr, junas1@add.re.kr

논문번호: KICS2014-02-045, Received February 6, 2014; Revised April 15, 2014; Accepted April 15, 2014, 2014 


\section{I. 서 론}

모노펄스 추적시스템은 일반적으로 레이더 및 위성 추적시스템에 적용 된다. 레이더추적시스템의 경우 특 정 공간좌표 상의 물체의 감지와 해당 범위 안에서 물 체의 위치를 추적한다 ${ }^{[1,2]}$. 위성추적시스템은 통신링크 를 안정적으로 유지하기 위해 안테나를 위성 방향으 로 지속적으로 지향시키도록 추적하는 시스템이다 ${ }^{[3]}$. 이러한, 위성추적을 위해서는 지속적으로 위성의 위치 및 지향오차 데이터가 안테나 구동을 위해 제공될 수 있어야 하며, 이를 위해 다양한 추적방식이 제안되고 있다. 추적방식으로는 안테나의 빔을 위성 근방에 주 사하여 비콘신호 수신레벨이 최대가 되도록 추적하는 로빙 방식과 단일 펄스를 이용하는 모노펄스 추적방 식이 있다 ${ }^{[4]}$. 이 중 모노펄스 추적방식은 한 번의 전파 신호수신으로 순간적으로 추적오차를 검출하여 추적 하는 방식으로서 다른 추적방식에 비하여 목표물의 빠른 추적이 가능한 것과 고정밀도의 방위정보를 얻 을 수 있는 장점이 있다. 모노펄스 추적방식은 여러 개의 복사기를 이용하는 다중 혼 모노펄스 추적방식 과 급전부의 원형 도파관 내에 발생하는 고차모들] (안테나 지향방향이 전파 입사 방향의 중심축에서 벗 어났을 때 발생)를 이용하는 다중모드 모노펄스 추적 방식으로 나누어진다 ${ }^{[6]}$.

본 논문에서는 $\mathrm{Ku}$ 대역 모노펄스 위성추적을 위한 동축구조 도파관 고차모드 커플러를 제안하였다. 2장 에서는 다중모드 모노펄스 위성추적을 위해 안테나로 입사된 오차신호를 정의하고, 오차신호의 추출을 위해 동축구조 도파관 고차모드 커플러를 제안하며 원리를 설명한다. 3장에서는 제안된 구조에 대하여 모노펄스 추적용 오차신호 추출을 위해 요구되는 특성이 만족 됨을 모의실험을 통해 보이며 4장에서 결론을 맺는다.

\section{II. 본 론}

\section{1 다중모드 모노펄스 위성추적}

다중모드 모노펄스 위성추적에서는 안테나 빔축이 위성의 방향으로부터 벗어났을 때 안테나로 여기되는 고차모드( $\mathrm{TE}_{21}$ mode) 신호와 기본모드( $\mathrm{TE}_{11}$ mode) 신호를 이용하여 위성추적을 위한 오차정보를 얻는다. 추적오차정보를 얻는 방법은 그림 1 의 추적오차신호 분석 좌표계를 통하여 설명할 수 있다. $\mathrm{x}, \mathrm{y}$ 축의 면은 안테나 개구면을 나타내며 원점을 중심으로 변위 값 을 좌표상에서 $\triangle \mathrm{x}$ 과 $\triangle \mathrm{y}$ 로 정의한다. 안테나 개구면 에 입사되는 전계를 수평성분 $\left(\mathrm{E}_{\mathrm{x}}\right)$ 과 수직성분 $\left(\mathrm{E}_{\mathrm{y}}\right)$ 으로

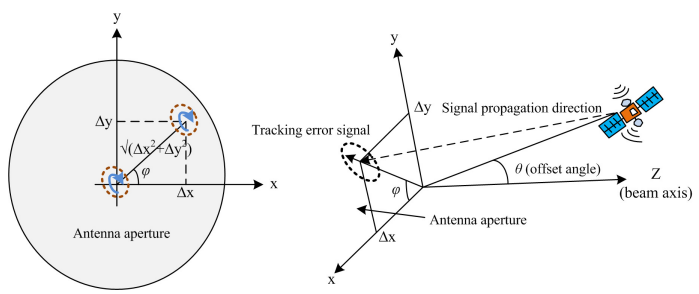

그림 1. 추적오차신호 좌표계 분석

Fig. 1. Coordinate system of tracking error signal analysis

분리하여 수식(1)로 나타낼 수 있다.

$\mathrm{E}_{\mathrm{z}}=\mathrm{E}_{0} \sin \omega \mathrm{t}, \mathrm{E}_{\mathrm{y}}=\mathrm{E} 0 \cos \omega \mathrm{t}$

여기서, $\mathrm{E}_{0}$ 는 입사되는 신호의 진폭이며 $\omega$ 는 각주파 수이다. 또한, 그림1에서 안테나가 빔 축(On axis)으 로부터 벗어났을 때의 빔 축과 위성지향방향 사이의 각도를 $\Theta$ 라 정의하며 이를 안테나 개구면에 투영하여 형성되는 각도를 $\phi$ 라 정의한다.

이제 안테나가 위성방향에서 벗어났을 때 형성되는 고차모드 커플러의 전계성분을 분석하고자 한다. 분석 에 대한 설명은 현재 $\mathrm{Ku}$ 대역 상용위성에 사용되고 있 는 선형편파를 기준으로 한다. 또한, 선형편파의 경우 수평편파와 수직편파로 나누어지는데, 여기서는 편의 상 수평편파를 기준으로 설명하며, 수직편파일 경우는 수평편파와의 직교 위상 관계를 고려하여 수평편파와 같은 원리로 분석이 가능하다.

그림 2는 안테나가 위성방향으로부터 벗어났을 때 수평 및 수직방향으로 이동시 형성되는 고차모드 성 분의 해석 모델을 나타낸다. 수평 $(\triangle \mathrm{x})$ 및 수직 $(\triangle \mathrm{y})$

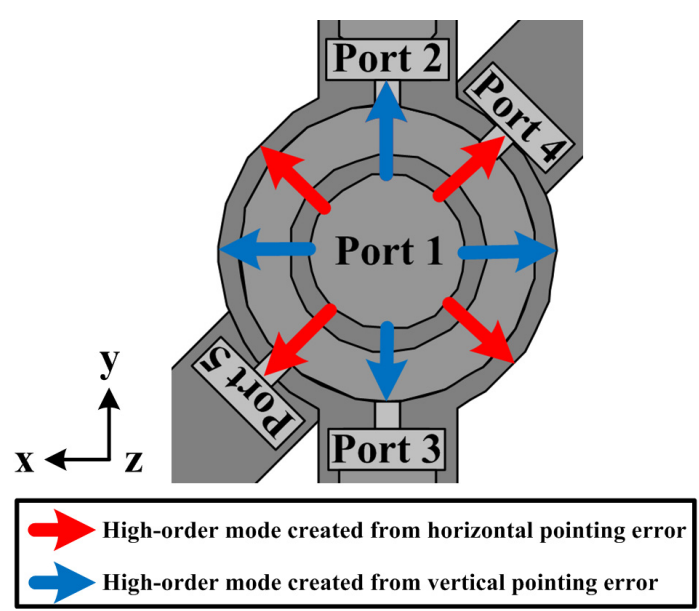

그림 2. 고차모드 커플러의 해석 모델

Fig. 2. Analysis model of higher-order mode coupler 
방향으로 벗어났을 때 형성되는 고차모드 전계성분의 추출은 4 개의 포트를 이용한다. 포트 2 와 포트 4 로 추 출되는 신호의 위상차가 90도이며, 포트 3과 포트5로 추출되는 신호 역시 90 도 위상차를 갖는다. 기본모드 전계성분의 추출은 포트 1 을 사용한다. 그림을 보면 안테나가 수평방향으로 벗어났을 때 형성되는 전계의 수평성분 $\left(\triangle \mathrm{xE}_{\mathrm{x}}\right)$ 을 포트 2,3 을 통해 추출되고, 수직방 향으로 벗어났을 때 형성되는 전계의 수평성분 $\left(\triangle \mathrm{yE}_{\mathrm{y}}\right)$ 을 포트 4,5 를 통해 추출한다.

추출된 2 개의 전계수평성분은 90 도 하이브리드 커 플러를 통과하여 90도 위상차로 합성되고, 이를 아래 수식 (2)로 나타낼 수 있다마.

$$
\triangle y E_{x}+\mathrm{j} \triangle \mathrm{xEx}
$$

여기서, $\mathrm{E}_{\mathrm{x}}$ 와 $\mathrm{E}_{\mathrm{y}}$ 는 직교 위상 관계이므로 수식(3)으 로 나타낼 수 있다.

$$
\triangle \mathrm{yEx}+\mathrm{j} \triangle \mathrm{xEx}=\triangle \mathrm{yEx}+\triangle \mathrm{xEy}
$$

또한, 수식 (1)을 수식 (3)에 대입하여 다음과 같이 정리 할 수 있다.

$$
\begin{aligned}
& \triangle \mathrm{yE}_{\mathrm{x}}+\triangle \mathrm{xE}_{\mathrm{y}} \\
= & \mathrm{E}_{0} \triangle \mathrm{y} \sin \omega \mathrm{t}+\mathrm{E}_{0} \triangle \mathrm{x} \cos \omega \mathrm{t} \\
= & \mathrm{E}_{0}(\triangle \mathrm{y} \sin \omega \mathrm{t}+\triangle \mathrm{x} \cos \omega \mathrm{t})
\end{aligned}
$$

그림 1을 참조하여 $\triangle \mathrm{x}$ 와 $\triangle \mathrm{y}$ 를 아래와 같이 수식 (5)로 나타낼 수 있다.

$$
\begin{aligned}
& \triangle \mathrm{x}=\cos \phi \times \sqrt{ }\left(\triangle \mathrm{x}^{2}+\triangle \mathrm{y}^{2}\right) \\
& \triangle \mathrm{y}=\cos \phi \times \sqrt{ }\left(\triangle \mathrm{x}^{2}+\triangle \mathrm{y}^{2}\right)
\end{aligned}
$$

위 수식 (5)를 수식 (4)에 대입하여 수식 (6)을 얻을 수 있다.

$$
\begin{aligned}
& \mathrm{E}_{0}(\triangle \mathrm{y} \sin \omega \mathrm{t}+\triangle \mathrm{x} \cos \omega \mathrm{t}) \\
& =\mathrm{E}_{0} \sqrt{ }\left(\triangle \mathrm{x}^{2}+\triangle \mathrm{y}^{2}\right) \times(\sin \phi \sin \omega \mathrm{t}+\cos \phi \cos \omega \mathrm{t}) \\
& =\mathrm{E}_{0} \sqrt{ }\left(\triangle \mathrm{x}^{2}+\triangle \mathrm{y}^{2}\right) \times \cos (\omega \mathrm{t}-\phi)
\end{aligned}
$$

수식 (4)로 표현된 90도 하이브리드 커플러 통과후 의 전계성분에서 $\sqrt{ }\left(\Delta x^{2}+\Delta y^{2}\right)$ 은 그림1의 $\Theta$ (offset angle)에 비례하는 값으로 다음 수식으로 나타낼 수 있다.

$$
\sqrt{ }\left(\triangle \mathrm{x}^{2}+\triangle \mathrm{y}^{2}\right) \approx \mathrm{K} \Theta
$$

여기서 K는 K-factor라 하며 $\Theta$ 의 비례함수로 기본 모드 및 고차모드 전계성분 진폭 비(ratio)의 기울기로 정의된다 ${ }^{[8]}$.

그림 3은 기본모드 및 고차모드의 안테나 방사패턴 해석 모델을 나타낸다. 기본모드 패턴곡선과 고차모드 패턴곡선이 만나는 좌우지점까지가 K-factor의 선형 성을 이루는 구간으로 이 범위 내에서 다중모드 모노 펄스 추적이 가능하다. 고차모드 패턴의 null 깊이가 깊을수록 $\mathrm{K}$ 의 크기는 증가되며 이는 곧 $\Theta$ 와 곱해진 다. $\Theta$ 는 작은 값을 갖는다는 가정과 크기가 작은 $\mathrm{K}$ 와 크기가 큰 $\mathrm{K}^{\prime}$ 으로 가정한다. $\Theta$ 는 $\mathrm{K}$ 또는 $\mathrm{K}^{\prime}$ 과 곱해지 고 이를 분석하면 $\mathrm{K} \ominus$ 는 $\ominus$ 의 작은 값이 그대로 유지 되면서 추적오차신호를 식별할 수 없을 만큼의 성분 을 추출하게 된다.

반면, 크기가 큰 $\mathrm{K} \ominus$ 의 경우 앞서 가정한 $\Theta$ 에 대해 추적오차신호를 식별할 수 있는 성분을 쉽게 추출할 수 있다. 즉, $\Theta$ 가 작은 값을 갖더라도 $\Theta$ 에 대한 성분 을 얻을 수 있으며 이는 곧 K-factor로 인해 고정밀도 의 $\Theta$ 를 구현할 수 있다.

이처럼, 기본모드와 고차모드 패턴 특성을 이용한 지향 오차를 구하는데 있어서 안정적인 전계성분 추 출은 고정밀도 및 고속추적을 구현하는 중요한 역할 을 하며, 전계성분의 추출을 담당하는 고차모드 커플 러의 성능이 매우 중요하다.

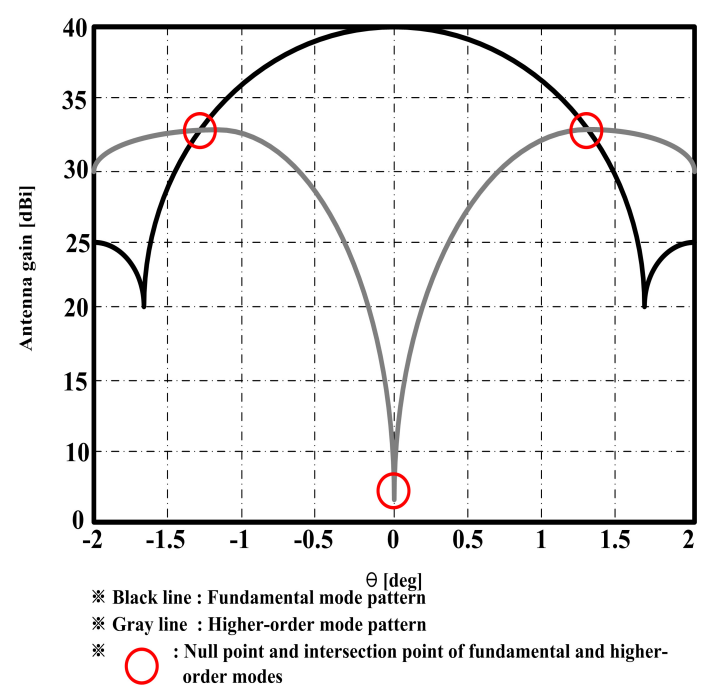

그림 3. 기본모드 및 고차모드 패턴 해석 모델

Fig. 3. Pattern analysis model of fundamental mode and higher-order mode 


\section{2 동축구조 도파관 고차모드 커플러 설계}

그림 4은 $\mathrm{Ku}$ 대역 동축구조 도파관 고차모드 커플 러의 3차원 모델을 나타낸다. 제안된 모델의 구조는 기존 고차모드 커플러미의 구조와는 달리 동축구조 도 파관을 제안하여 설계하였다. $\mathrm{Ku}$ 대역에서의 기본모드 동작을 위해 내측 원형도파관이 이용되고, 고차모드 동작을 위해 외측 원형도파관이 이용된다 ${ }^{[10]}$. 외측 및 내측 원형도파관의 직경은 각각 $14.87 \mathrm{~mm}, 28.41$ $\mathrm{mm}$ 이다. 고차모드 전계신호의 가이드를 위해 4 개의 직사각형 도파관이 적용되며 개구면의 크기는 4 개의 직사각형 도파관 모두 $9.35 \mathrm{~mm} \times 18.73 \mathrm{~mm}(\mathrm{z} \times \mathrm{y})$ 의 같은 크기를 갖는다. 포트 1은 원형도파관으로 인가되 며 포트 $2,3,4,5$ 은 각각의 직사각형 도파관에 아래 그림 4 와 같이 인가된다. 이와 같이 설계된 동축구조 도파관은 기본모드와 고차모드 신호의 격리도 특성 개선효과와 이동체 탑재용 추적시스템에 적용 가능한 소형/경량화의 이점이 있다.

그림 5 는 그림 4 의 단면을 나타낸다. 기본모드 성 분 추출을 위한 내측 원형도파관과 고차모드 성분 추

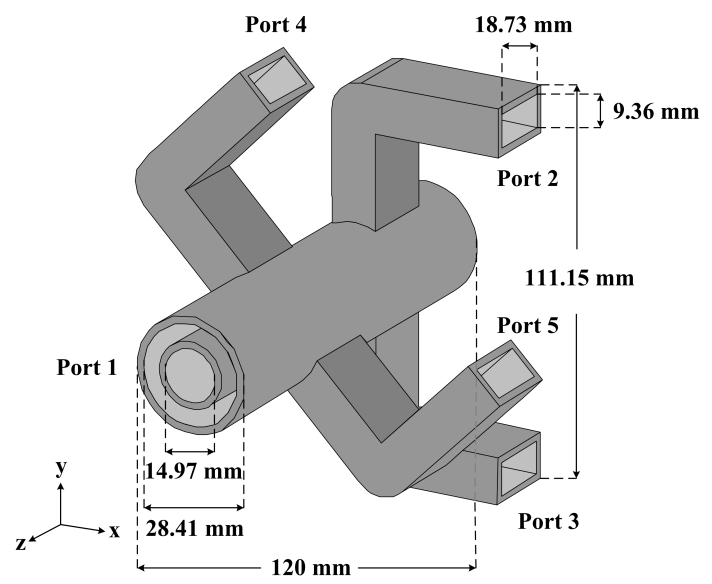

그림 4. 제안된 고차모드 커플러의 3차원 모델

Fig. 4. 3D model of proposed higher-order mode coupler

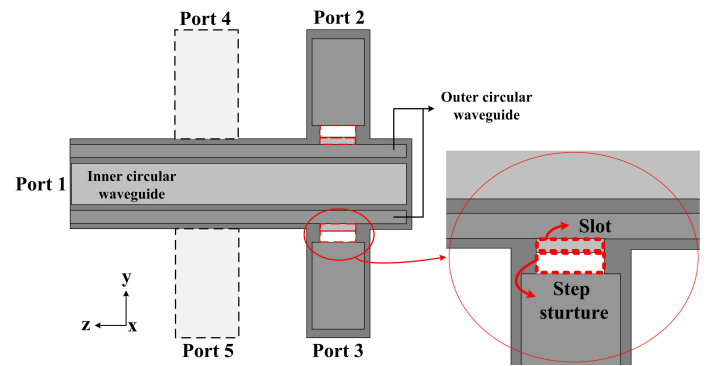

그림 5. 고차모드 커플러의 단면

Fig. 5. Cross section of higher-order mode coupler
출을 위한 외측 원형도파관 및 슬롯, 그리고 스텝구조 직사각형 도파관 구조가 보인다. 슬롯의 크기는 12.73 $\mathrm{mm} \times 2.368 \mathrm{~mm} \times 2.55 \mathrm{~mm}(\mathrm{z} \times \mathrm{X} \times \mathrm{y})$ 이며 직사각형 도 파관과 결합하게 된다. 스텝구조의 크기는 12.73 $\mathrm{mm} \times 8.37 \mathrm{~mm} \times 4 \mathrm{~mm}(\mathrm{z} \times \mathrm{X} \times \mathrm{y})$ 이며 결합된 슬롯과 직 사각형 도파관의 임피던스 정합을 위해 둘 사이에 추 가된 구조이다. 여기서, 슬롯과 스텝구조의 크기는 고 차모드 성분의 안정적 추출을 위한 중요한 값으로 조 정을 통해 최적화 하였다.

\section{III. 모의실험}

상용프로그램을 이용해 제안된 고차모드 커플러의 특성 확인을 위한 모의실험을 실시하고 결과에 대해 분석하였다. 그림 6 는 제안된 고차모드 커플러의 산란 파라메터 특성을 나타낸다. 그림 6(a)는 포트 1의 반 사손실 $\left(\mathrm{S}_{11}\right)$ 과 포트 1 로부터 포트 2,3 으로의 전달계 수 $\left(\mathrm{S}_{21}, \mathrm{~S}_{31}\right)$ 를 나타낸다. 반사손실 특성은 $-15 \mathrm{~dB}$ 기 준으로 $\mathrm{Ku}$ 대역에서 약 $250 \mathrm{MHz}$ 의 대역폭(12.75 $13.00 \mathrm{GHz}$ )을 만족하며 전달계수는 $-3 \mathrm{~dB}$ 의 반전력 분배 특성을 만족한다.

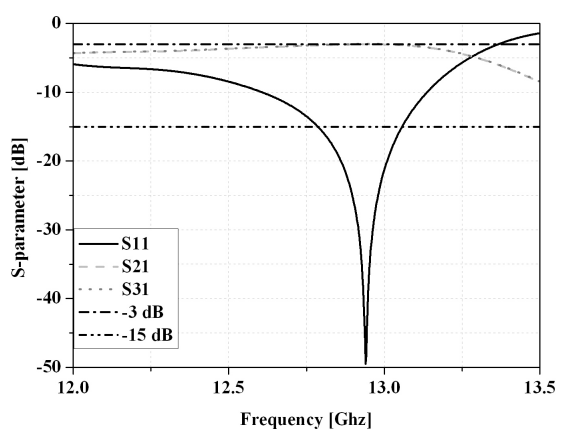

(a) 포트 1,2,3

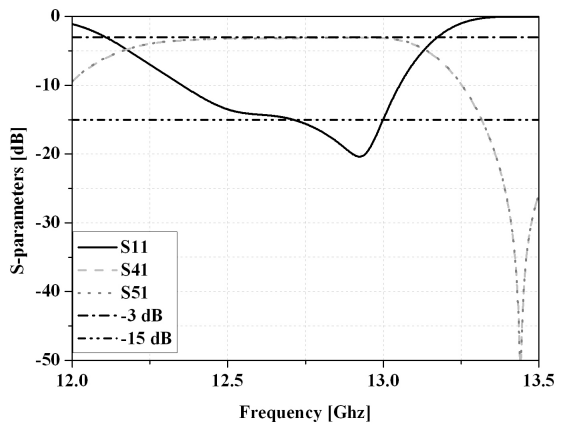

(b) 포트 1,4,5

그림 6. 고차모드 커플러의 산란파라메터 특성

Fig. 6. S-parameter characteristics of higher-order mode coupler 
그림 6(b)는 포트 1의 반사손실과 포트 1로부터 포 트 4,5 로의 전달계수 $\left(\mathrm{S}_{41}, \mathrm{~S}_{51}\right)$ 를 나타낸다. 역시 반사 손실은 $-15 \mathrm{~dB}$ 기준으로 약 $250 \mathrm{MHz}$ 의 대역폭(12.75 $\sim 13.00 \mathrm{GHz})$ 을 만족하며, 전달계수는 $-3 \mathrm{~dB}$ 의 반 전력 분배 특성을 만족한다.

그림 7.(a)은 제안된 고차모드 커플러의 기본모드 전계분포(포트 1)의 모의실험 결과를 나타낸다. 아래 에서 위로 직립된 전계분포 모양으로부터 원형도파관

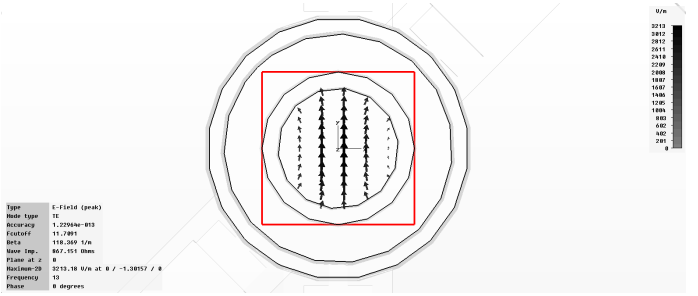

(a) 전계분포

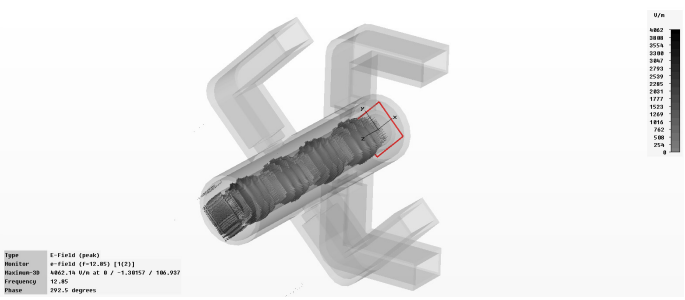

(b) 전계흐름

그림 7. 내측 원형도파관에서의 기본모드 전계 (포트 1) Fig. 7. Fundamental mode E-field of the inner circular waveguide (Port 1)
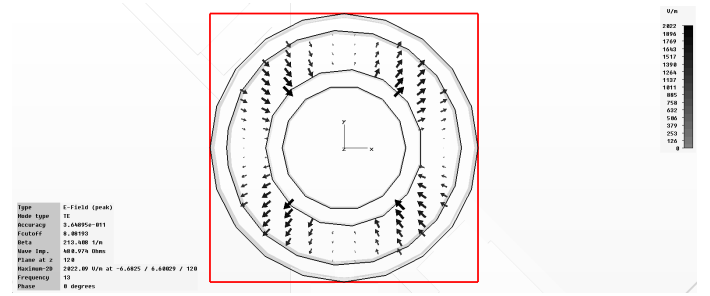

(a) 전계분포

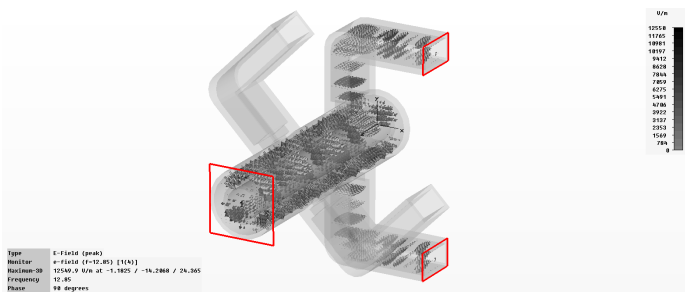

(b) 전계흐름

그림 8. 외측 원형도파관에서의 고차모드 전계 (포트 $1,2,3)$ Fig. 8. Higher-order mode E-field of the outer circular waveguide (Port 1,2,3)
내측 전계성분이 기본모드로 형성됨이 확인 된다. 그 림 7(b)는 내측 원형도파관에서의 기본모드 전계흐름 을 나타낸다.

그림 8.(a)은 제안된 고차모드 커플러 고차모드 전 계분포(포트 1,2,3)의 모의실험 결과를 나타낸다. 원형 도파관 외측에서 전계성분이 대각선 방향으로 엇갈린 전계 분포 모양으로부터 외측원형도파관에서의 전계 성분이 고차모드로 형성됨을 알 수 있다. 그림 8.(b)는 외측원형도파관에서의 고차모드 전계흐름을 나타낸 다. 외측 원형 도파관에서 흐르는 전계성분이 슬롯을 통해 커플링되어 직사각형 도파관으로 흐르는 것을 확인할 수 있다.

포트 2,3과 90도의 위상차를 갖는 구조에 대해서도 전계분포 및 흐름(포트 $1,4,5)$ 이 동일하게 나타나는 것을 그림 9 를 통해 알 수 있다.

그림 10 은 제안된 고차모드 커플러의 기본모드 및 고차모드 방사패턴 모의실험 결과를 나타낸다. 기본모 드 패턴은 내측 원형도파관으로 전파되는 기본모드 신호를 이용하여 얻어지고, 고차모드 패턴은 외측 원 형도파관에서 커플링되어 추출된 신호 성분들을 하이 브리드 커플러를 통과시킴으로써 합성된 신호를 이용 하여 얻어진다. 고차모드 패턴 이득은 기본모드 패턴 이득 대비 $2 \mathrm{~dB}$ 낮으며 고차모드 패턴의 null 깊이는 $30 \mathrm{~dB}$ 이다. 형성된 기본모드 패턴과 고차모드 패턴이 그림 3의 패턴 해석 모델에서 설명된 것처럼 모노펄 스 추적용 정밀 지향오차각 추출에 활용될 수 있는 적

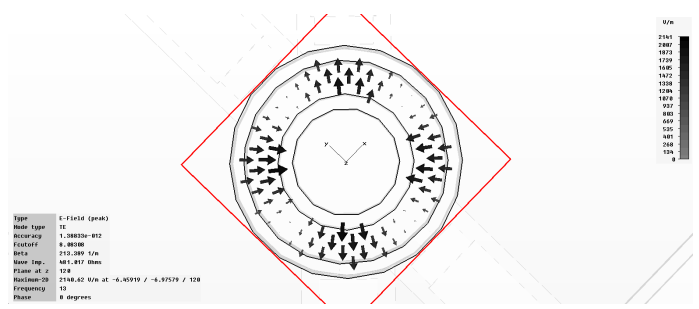

(a) 전계분포

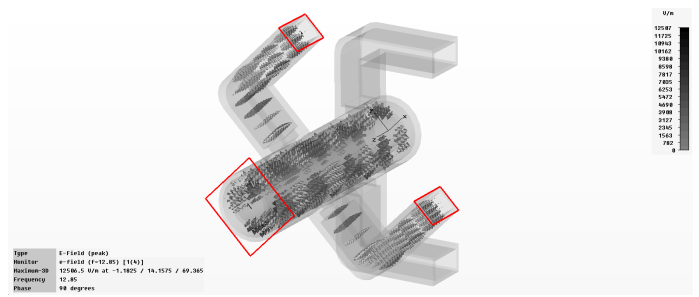

(b) 전계흐름

그림 9. 외측 원형도파관에서의 고차모드 전계 (포트 1,4,5) Fig. 9. Higher-order mode E-field of the outer circular waveguide (Port 1,4,5) 


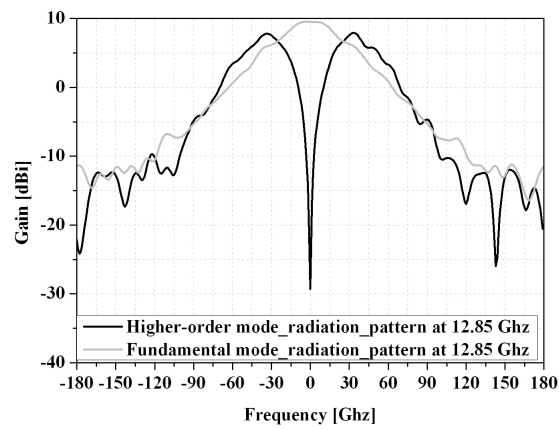

(a) 포트 1,2,3

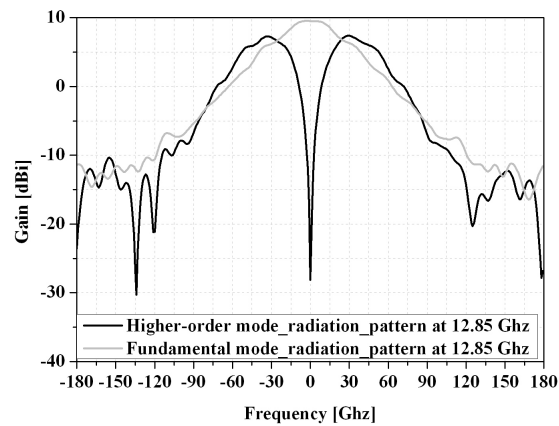

(b) 포트 1,4,5

그림 10. 고차모드 커플러의 고차모드 및 기본모드 방사패턴 Fig. 10. Radiation patterns of the higher-order mode and fundamental mode of the higher-order mode coupler

\section{IV. 결 론}

본 논문에서는 모노펄스 위성추적시스템에 유용하 게 활용될 수 있는 동축구조 도파관 고차모드 커플러 를 제안하였다. 제안된 고차모드 커플러는 높은 격리 도 특성 및 소형/경량화의 장점을 갖는 동축구조를 이 용하여 기본모드와 고차모드를 분리 생성하였고, 고차 모드 신호 추출을 위해 슬롯과 스텝구조의 직사각형 도파관을 이용하였다. 슬롯과 직사각형 도파관의 임피 던스 정합을 위해 스텝구조가 적용되었다. 제안된 고 차모드 커플러는 $\mathrm{Ku}$ 대역에서 약 $250 \mathrm{MHz}$ 의 대역폭 을 가지며 전달계수는 $-3 \mathrm{~dB}$ 의 반전력 분배 특성을 만족한다. 추출된 신호로부터 생성된 기본모드 패턴 및 고차모드 패턴은 모노펄스 추적용 지향오차 추출 에 활용될 수 있도록 요구되는 특성을 제공한다. 제안 된 $\mathrm{Ku}$ 대역 동축구조 도파관 고차모드 커플러는 고속 정밀추적이 요구되는 이동체 탑재용 모노펄스 위성추 적에 이용될 것으로 기대된다.
[1] M. I. Skolnik, Introduction to Radar Systems, $3^{\text {rd }}$ Ed., NY: McGraw-Hill Education, 2001.

[2] Y. M. Koh and K. H. Ra, "Design of image rejection SSB modulator for X-band monopulse RADAR using waveguide hybrid coupler," J. IEIE, vol. 48, no. 6, pp. 34-40, Jun. 2011.

[3] G. Maral and M. Bousquet, Satellite Communications Systems, $5^{\text {th }}$ Ed., NY: John Wiley \& Sons, 2009.

[4] Telecommunications Technology Association, Tracking system, Retrieved Jan. 6, 2014, from http://www.tta.or.kr.

[5] D. H. Park, C. H. Song, C. W. Jun, D. H. Park, G. H. Baek, and S. P. Kim, "A multi-mode monopulse tracking system for satellite communication," KIEES conf., p. 104, Incheon, Korea, Dec. 2009.

[6] G. J. Hawkins, D. J. Edwards, and J. P McGeehan, "Tracking systems for satellite communications," IEE Proc. Radar and Signal Processing, vol. 135 , no. 5, pp. 393-407, Oct. 1988.

[7] L. Sakr, "The higher order modes in the feeds of the satellite monopulse tracking antennas," IEEE MELECON, pp. 453-457, Cairo, Egypt, May 2002.

[8] J. Nateghi, L. Mohammady, and E. Jedari, "Analysis of the TE21 mode monopulse tracking technique in LEO satellite systems," IEEE AICT, pp. 42-45, Athens, Greece, Jun. 2008.

[9] Y. H. Choung, K. R. Goudey, and L. G. Bryans, "Theory and design of a Ku-band TE21-mode coupler," IEEE MTT, vol. 30, no. 11, pp. 18621866, Nov. 1982.

[10] D. M. Pozar, Microwave Engineering, $3^{\text {rd }}$ Ed., NY: John Wiley \& Sons, 2009. 


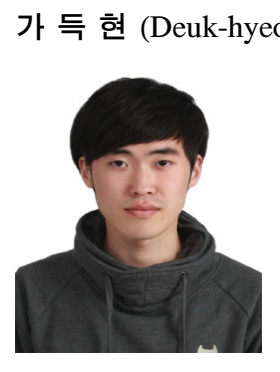

2011년 2월 : 한남대학교 정보 통신 공학과 졸업

2013년 2월 : 한양대학교 전자 컴퓨터통신 공학과 석사

2013년 1월 현재 : LIG 넥스원 연구원

<관심분야> 안테나, 위성통신, 추적시스템

박 도 현 (Do-hyun Park)

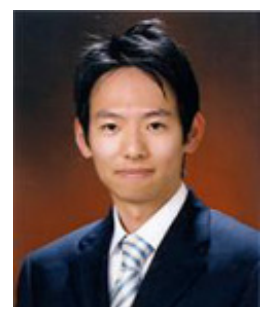

2006년 2월 : 경희대학교 전파 통신 공학과 졸업

2006년 7월 : LG디스플레이 사원 2006년 7월 현재 : LIG넥스원 선임연구원

<관심분야> 안테나, 위성통신

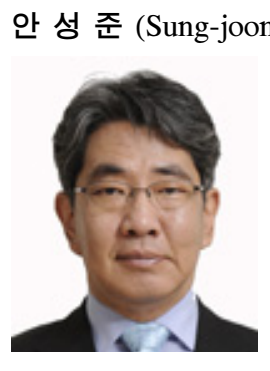

안 성 준 (Sung-joon Ahn)

1984년 2월 : 연세대학교 전자 공학과 졸업

1986년 2월 : 연세대학교 전자 공학과 석사

1987년 2월 현재 : 국방과학연 구소 연구원

<관심분야> 전자공학, 통신공 학, 위성통신

전 찬 원 (Chan-won Jun)

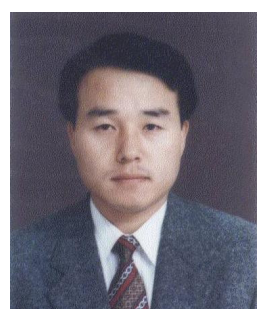

1989년 2월 : 한국항공대학교 항 공기계 공학과 졸업

2002년 2월 : 배제대학교 정보통 신 공학과 석사

2005년 8월 : 배제대학교 정보통

신 공학과 박사

1989년 11월 현재 : 국방과학연

구소 연구원

<관심분야> 안테나, 위성통신, 무인기 위성안테나

이 재 문 (Jae-moon Lee)

송 충 호 (Choong-ho Song)

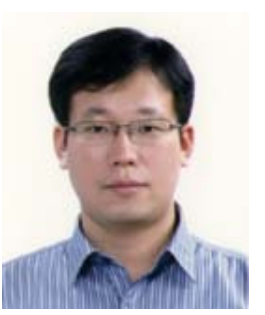

2002년 2월 : 한양대학교 전자

통신 공학과 박사

2002년 3월 : LIG넥스원 수석

연구원

<관심분야> 안테나, 위성통신,

추적시스템

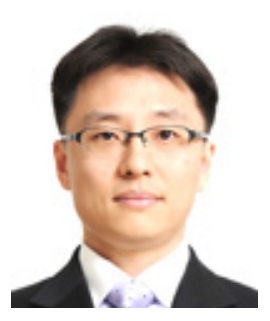

2000년 2월 : 한양대학교 전자 통신전파 공학과 졸업 2002년 2월 : 한양대학교 전자

통신전파 공학과 석사

2002년 1월 현재 : 국방과학연

구소 연구원

2012년 3월 현재 : 아주대학교

컴퓨터공학과 박사과정

<관심분야> 안테나, 통신공학, 추적시스템 